\title{
ПОРУШЕННЯ РОЗВИТКУ СТАТІ В УКРАЇНІ: НАШ ДОСВІД
}

\author{
Н.Б. Зелінська ${ }^{1}$, С.В. Глоба ${ }^{1}$, І.Ю. Шевченко ${ }^{1}$ Ю.О. Щербак ${ }^{2}$

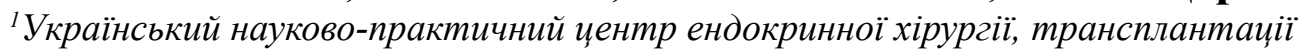 \\ ендокринних органів і тканин МОЗ України, м. Київ \\ ${ }^{2}$ Начіональна дитяча спечіалізована лікарня «ОХМАТДИТ» МОЗ Украӥни, м. Київ
}

Мета. Консенсусом щодо порушень розвитку статі (ПРС) затверджено зміни в термінології та виділено три групи інверсії статі - 3 хромосомними порушеннями, 3 нормальним чоловічим та 3 нормальним жіночим каріотипом. Метою дослідження було визначення частоти, клінічного поліморфізму та генетичної гетерогенності випадків ПРС в Україні.

Матеріали іметоди.Проведено ретроспективний аналіз 75 медичних карт пацієнтів з ПРС з 2000 по 2017 роки. Наша база даних була створена на основі самозвернення пацієнтів та не поширюється на всіх дітей з ПРС в Україні. Критерієм включення пацієнтів до бази даних була неправильна чи невизначена будова зовнішніх геніталій та/або невідповідність гонадної статі хромосомній. На момент обстеження кількість хворих віком до 1 місяця становила 17\%, від 1 місяця до 1 року - 25\%, віком 1-12 років - 37\% та старше 12 років - 21\%. Проаналізовано результати клінічних даних, анамнезу, лабораторних, гормональних, функціональних та інструментальних обстежень.Всімпацієнтампроводилицитогенетичне дослідження (каріотипування за стандартною методикою) та, за необхідності, молекулярноцитогенетичне (флюоресцентна гібридизація in situ (FiSH-метод). Молекулярно-генетичне тестування проведено в обраній групі пацієнтів 3 46,XY ПРС в лабораторіях України $(\mathrm{n}=2)$ та інституті Пастера, Франція ( $\mathrm{n}=19)$, з використанням повного екзомного секвенування.

Результати та обговорення. Хромосомне ПРС діагностували у $21,3 \%(n=16)$ пацієнтів, $46, X Y$ ПРС - у $64 \%(n=48)$ та 46,XX ПРС - у 14,7\% (n=11) випадків.

Найбільш частим варіантом каріотипу серед пацієнтів першої групи був каріотип 45,X/46,XY (n=5; $31,2 \%)$.

Вгрупіпацієнтів 346,XYПРС за клінічними ознаками було встановлено такі попередні діагнози: синдром нечутливості до андрогенів, повна та часткова форми $(n=21)$, ПРС, промежинна гіпоспадія $(n=7)$, ПРС, повний гонадальний дизгенез $(\mathrm{n}=6)$, синдром тестикулярної регресії $(\mathrm{n}=5)$, частковий гонадальний дизгенез $(\mathrm{n}=3)$ та ПРС, овотестикулярний варіант $(n=2)$.

Генетичне тестування в даній групі було проведено у 21 (44\%) пацієнтів. В п'яти випадках було виявлено мутації в «класичних» генах, що спричиняють порушення розвитку яєчок, а саме - В генах CBX-2 $(n=1)$, WT1 $(n=1)$ та NR5A1 $(n=3)$. Серед групи пацієнтів 46,XY ПРС 3 порушенням синтезу/ дії андрогенів були знайдені мутації в таких генах як AR $(n=5), \operatorname{SRD} 5 A 2(n=1)$ та HSD17B3 $(n=1)$. У одного пацієнта 3 синдромом персистуючої Мюллерової протоки підтверджена мутація в гені AMHR2. У 4 пацієнтів (19\%) знайдені гени не відповідали фенотипу i їх зв'язок $з$ наявним захворюванням має бути доведений в подальших дослідженнях. У 4 (19\%) пацієнтів мутацій не було виявлено.

У групі пацієнтів 3 46,XX ПРС діагностовано: тестикулярне 46,XX ПРС $(n=5)$, дефіцит 21-гідроксилази з рівнем вірилізації IV-V за Prader $(n=4), 46, X X$ гонадальний дизгенез $(n=1)$ і ПРС в VACTER-асоціації $(n=1)$.

Серед всіх пацієнтів у 8\% випадків реєстрація громадянської статі була змінена протягом перших двохроківжиття.Створена багатопрофільна команда для визначення гендерної статі у новонароджених 3 ПРС та вдосконалення тактики подальшого спостереження, включаючи вік гонадектоміі.

Висновки. Всім пацієнтам з ПРС необхідно рекомендувати проведення генетичного обстеження, оскільки наявна клінічна картина, лабораторне та інструментальне обстеження не завжди дозволяють встановити точний діагноз, обгрунтувати тактику подальшого обстеження, спостереження, ураження інших органів-мішеней, час проведення реконструктивних операцій, гонадектомії тощо. Потрібні подальші дослідження для виявлення нових генів, що викликають ПРС.

\section{ЛITEPATУPA}

1. Lee PA, Houk P, Ahmed FS, et al. Consensus Statement on Management of Intersex Disorders. Pediatrics. 
2006; 118 (2):488-500.

2. Parisi MA, Ramsdell LA, Burns $M W$, et al. Gender Assessment Team: experience with 250 patients over a period of 25 years. Genet Med. 2007; 9(6):34857.

Дата надходження до редакції 08.10.2018р.
3. Shcherbak $Y$, Globa $Y$, Zelinska $N$, Shevchenko I. [Disorders of testicular development in persons with 46, XY-gonadal dysgenesis]. Clinical Endocrinology and Endocrine Surgery. 2018; (3):15-21. [Ukrainian].

https://doi.org/10.24026/1818-1384.4(64).2018.150171

\title{
РАННЕЕ ВЫЯВЛЕНИЕ СУБКЛИНИЧЕСКОГО АТЕРОСКЛЕРОЗА И ДИАБЕТИЧЕСКОЙ АНГИОПАТИИ У ПАЦИЕНТОВ С САХАРНЫМ ДИАБЕТОМ ПО РЕЗУЛЬТАТАМ ДУПЛЕКСНОГО СКАНИРОВАНИЯ АРТЕРИЙ
}

\author{
О.А. Ковалевская, З.Г. Крушинская, И.О. Чувикина, О.М. Желиба \\ Украинский научно-практический центр эндокринной хирургии, трансплантации \\ эндокринных органов и тканей МЗ Украинь
}

Цель: Изучить возможности и диагностическое значение ультразвукового дуплексного сканирования в оценке субклинических изменений артериальной стенки у больных сахарным диабетом.

Материалы и методы. Нами обследовано 2264 пациента с сахарным диабетом 2 типа (средний возраст 62 года), которые находились на стационарном лечении, и 1972 пациента (средний возраст 54 года), которые проходили обследование и лечение амбулаторно в УНПЦЭХиТЭОиТ (г. Киев).

Пациентам выполнены стандартные клинические, лабораторные и инструментальные исследования, ультразвуковые исследования сердечнососудистой системы (эхокардиография, дуплексное сканирование периферических артерий), все пациенты проконсультированы кардиологом.

При наличии показаний выполнялись КТангиография с контрастированием, рентгенконтрастная ангиография коронарных и периферических артерий.

Результаты и обсуждение. Большинству пациентов (83\%), которые попадают в специализированные лечебные учреждения с поздними сосудистыми осложнениями СД, ультразвуковые исследования сердца и сосудов ранее не назначались и не выполнялись. Эректильная дисфункция - это маркер поражения эндотелия, и может рассматриваться как ранний и значимый независимый фактор риска СД и ССЗ, особенно у мужчин молодого возраста. Коронарная болезнь при сахарном диабете характеризуется бессимптомным, атипичным течением. Диабетическая полинейропатия и малоподвижный образ жизни у пациентов с сахарным диабетом приводят к отсутствию жалоб на I-II стадиях хронической ишемии и обращению за медицинской помощью на III-IV стадиях хронической ишемии нижнихконечностей.Придуплексномсканировании периферических артерий изменения, характерные для диабетической макроангиопатии, выявлены у 97\% пациентов с СД 2 типа. Облитерирующий атеросклероз артерий нижних конечностей выявлен у 26-47\% обследованных пациентов, сосудов головного мозга - у 35-53\%, ИБС - у 55-84\% (в зависимости от анализируемых подгрупп).

\section{Выводы}

1.Ультразвуковаядопплерография (УЗДГ-«слепой допплер») и расчёт лодыжечно-плечевого индекса не позволяют выявить ранние субклинические изменения артериальной стенки.

2. Поскольку 65-70\% пациентов с СД 2 типа имеют поражение берцовых артерий с прогрессирующим развитием кальцифицирующего склероза, измерение АД в берцовых артериях при УзДг может быть некорректным и не отражать истинного состояния кровотока в дистальных сегментах нижних конечностей.

3. Дуплексное сканирование артерий позволяет выявить и оценить степень выраженности как начальных субклинических, так и гемодинамически значимых изменений периферических артерий, и является основным методом диагностики и 